\title{
ECONOMIC CRISIS AS A SOURCE OF MOTIVATION RISK IN THE HOTEL INDUSTRY:THE CASE OF THE NOVOTEL HOTEL IN SZCZECIN
}

\author{
A. Tokarz-Kocik \\ Department of Tourism Management \\ Faculty of Management and Economics of Services \\ University of Szczecin, Poland
}

\begin{abstract}
This article consists of two parts. The first part of the study characterizes the essence and the main areas of motivation risk in an enterprise, while the other shows the changes in the motivation of staff at the Novotel Hotel in connection with the economic crisis. This article is the result of literature study and analysis of available secondary data related to the studied issue.

Keywords: economic crisis, motivation risk, hotel industry
\end{abstract}

\section{Introduction}

An important element in determining the functioning of a hotel enterprise is adequate quality of labor. The functional nature of the hospitality service determines that the behavior and abilities of employees serving clients have a decisive impact on the usability of the final product. This causes the growing importance of the risk which brings about the hazard of disrupting the company's position due to poor staff attitudes, thereby delivering a product of quality not matching the expectations of the client.

The degree of involvement of staff in the provision of services depends to a large extent on the incentive policy, which in turn is determined by the economic situation of the company. The global economic crisis forced entrepreneurs to cut costs, which in practice lead to layoffs or reduction of funds for incentive systems.

The article attempts to identify the major risk factors in the implementation of the personnel function in the area of motivating employees in the activities of hotel enterprises in the context of economic crisis. This article is the result of literature study and analysis of available secondary data related to the analyzed issue.

\section{The essence of motivation risk}

Motivation risk is a kind of micro-social risk, that is, risk associated with the social system of an organization. It can be defined as engaging, under conditions of uncertainty, in activities of motivating staff that could fail. However, consciously acting to exert effects on employees, the company can increase its chances of not only survival, but also of development, with chances of human resources being enriched.

Human resource managers should determine what level of motivation risk they are willing to accept. The risked value (exposed to risk) in the case of personal risk may take both the material form (increased costs, lower profits, loss of competitiveness) and the intangible form (loss of reputation), but the latter often has implications of a financial nature as well. 
Even choice of timing and methods of implementation of activities aimed at motivating staff may be risky for the maintenance of particularly valuable human resources in the company. Inherent within motivation risk is the risk of selecting unsuitable motivators (incentives, persuasion, coercion) in relation to the needs of employees. An opportunity of incentives is their long-term effect and leaving the margin of freedom of action to employees (workers choose the behaviors that grant certain rewards), while an opportunity of persuasion is the appeal to intrinsic motivation, and its threat - the emotional impact on employees with all its consequences. Most threats are associated with the use of coercion, that is, submission of employee behavior to the will of the person motivating. This is because its use can generate risks of resistance or even sabotage actions.

A method of eliminating motivation risks in the area of remuneration is to relinquish fixed salaries, and use wide basic wage brackets [1].To obtain the best results of work, employees may be encouraged by the so called "risk-based pay". This form of remuneration consists in pairing a part of the wages directly with the performance of the employee or the organization. There is no guarantee that employees will receive similar amounts in the future. An increase in basic wages can happen only subject to changes of employee's position in the wage structure [2]. It seems, however, that this form of remuneration may increase the risk of demotivating those employees who do not achieve the desired results at the introduction of "risk-based pay". Risks associated with "time-based pay" for consist in failing to cater for the differences in the work performance obtained (both quantitative and qualitative), and therefore the potential loss of incentive effects. In turn, commission-based pay shifts economic risk of the company to the employee. The risk of conflicts over the use of this form of remuneration may decrease if it is replaced with time and commission based pay.

Motivation risk also entails the risk of erroneous motivation concepts. It is associated most often with a lack of or an incorrect diagnosis of the degree of satisfaction of individual needs of employees. It is important to minimize the negative consequences of risk of incoherence, that is, the lack of consistency in staff policies. It is particularly important to minimize the negative consequences of risk of incoherence with respect to motivation, through creation of a coherent system of financial and non-financial incentives to guide the behavior of employees [3].

To reduce the motivation risk related to the retention of specialists in the company, diagnoses must be constantly carried out in this respect, because there are differences between the needs of individual employees, and those needs change during the professional life of the employee.

\section{Changes in the incentive systems in the hotel industry due to the economic crisis: the case of the Novotel hotel in Szczecin}

The period of economic downturn that started in 2008, has affected the labor market in Poland. Due to their bad financial standing, employers were forced to reduce costs. Therefore, they refrained from creating new jobs, made changes in incentive systems, or chose to exempt employees. Similar phenomena also took place in the hotel industry, an instance of which might be the Novotel Hotel in Szczecin. The hotel was built in 2002. It is located in the city center, near the railway and bus stations and the major tourist 
attractions of Szczecin. The Novotel Hotel is part of the French hotel system Accor, which also includes such hotel chains as Sofitel, Mercure, Ibis and Etap.

In 2009, the Novotel hotel in Szczecin employed 47 persons, including 30 employees working under employment contracts and 17 under job performance contracts. The organizational structure in the Novotel Hotel is linear. The General Director oversees 11 functional departments. The responsibilities delineated for individual departments are presented in Table 1

Table 1. The responsibilities of employees at the Novotel Hotel in Szczecin

\begin{tabular}{|l|c|l|}
\hline DEPARTMENT & $\begin{array}{c}\text { Number of } \\
\text { employees }\end{array}$ & RESPONSIBILITIES \\
\hline Accounting & 1 & accounts, tax returns, management of cash \\
\hline Human Resources & 1 & employment policy, staff files, salaries \\
\hline Technical department & 2 & $\begin{array}{l}\text { technical supervision of hotel equipment, maintenance and } \\
\text { repair works }\end{array}$ \\
\hline Sales & 1 & $\begin{array}{l}\text { marketing strategy, promotional activities, contacts with the } \\
\text { press, competitive environment research }\end{array}$ \\
\hline Security & 4 & $\begin{array}{l}\text { protection of life and health of guests and staff, protection of } \\
\text { entrusted hotel property }\end{array}$ \\
\hline Reception & 8 & $\begin{array}{l}\text { booking rooms, checking-in and checking-out, informing } \\
\text { guests of the available hotel services }\end{array}$ \\
\hline Restaurant and bar & 10 & $\begin{array}{l}\text { preparing and serving drinks, serving meals in the restaurant } \\
\text { and rooms }\end{array}$ \\
\hline Housekeeping & 6 & $\begin{array}{l}\text { room service, taking guests' clothes to the laundry, taking dirty } \\
\text { and receiving clean bedclothes from the laundry, cleaning the } \\
\text { corridors and toilets on each floor }\end{array}$ \\
\hline Ronference department & 3 & $\begin{array}{l}\text { preparing meals, procurement of food products } \\
\text { rooms, guest service. }\end{array}$ \\
\hline Recreation center & 3 & $\begin{array}{l}\text { safeguarding the safety of guests using the pool, providing } \\
\text { professional service in the gym, equipment maintenance, } \\
\text { cleaning the recreational center, }\end{array}$ \\
\hline
\end{tabular}

Source: Own work.

Before the onset of economic crisis, the incentive scheme at the Novotel was based on financial and non-financial forms of motivation. Basic salaries of employees were relatively low, but employees were entitled to benefits such as:

- annual bonus $-50 \%$ of monthly salary, 
- allowance for working at night $-150 \%$ of the day rate,

- 7\%, seniority allowance - for employees employed longer than three years,

- $3 \%$ duty allowance for heads of departments,

- holiday bonuses - Christmas bonuses in the amount of 300 PLN in the form of Accor Services vouchers [4];

- commission for sales of high standard rooms and suites $-5 \%$ of the sale price per room.

The management of the Novotel Hotel also used non-financial motivation incentives. These were:

- meals for employees - hot meals provided for staff working under employment contracts,

- tickets for cultural events - awarded to outstanding employees for jubilees or other occasions

- training - at least one training a year for each employee,

- sports competition - free trip to the event along with accommodation for workers with outstanding performance record employed under employment contract.

The tourism sector is more exposed to the economic crisis than other industries. This stems from the fact that the flow of tourists from developed countries during the crisis becomes more limited both in terms of leisure travel, and in the business travel segment.

The Novotel Hotel in Szczecin has also felt the effects of the economic crisis. Decline in occupancy rates and lower prices per room caused a deterioration of the financial standing of the hotel. Reduction in revenue not only did not allow for continued development of the hotel, but also forced the management to introduce many changes aimed at reducing operational costs. The following changes to personnel management were introduced in 2009:

- the number of persons employed under job performance contracts was reduced,

- in contrast to previous years, with a higher occupancy of rooms, no new employees were hired, which means that employees were given more responsibilities for the same remuneration,

- the year-end bonus was reduced from $50 \%$ to $30 \%$ of the value of wages.

Another manifestation of the crisis was the cancellation of the annual sporting events in Gdansk for workers from across the ACCOR hotels group in Poland.

In addition to the pay-related changes that occurred in the reward system, the working atmosphere has deteriorated as well. The management exerted pressure on workers to increase sales, while showing no prospects of promotion or a raise. Lack of prospects for professional advancement, and low wages had a demotivating effect on employees. Several workers resigned, and the others were working with less commitment.

During a noticeable economic crisis, it is advisable to involve motivating tools of intangible nature. Therefore, the management of the Novotel Hotel should use more nonfinancial incentives, such as:

- showing recognition and appreciation for the staff's good service to visitors; this is a major tool in the motivation of senior staff (e.g. personally handing a letter of appreciation to the floor service manager for special dedication to maintaining cleanliness in the rooms in the last four weeks); 
- fostering a climate of cooperation - organize common tasks for a particular group (eg, asking all restaurant employees to develop a new breakfast menu);

- introduction of flexible working hours - especially for floor service workers,

- rotation of staff in job positions - in a situation when raises, promotions and trainings are withheld, it is important to look for challenges or change of responsibilities; workers can thus develop, gain new experience

In order to improve the human resources management system, including the motivating of employees, the management of the Novotel hotel should create a specialized department dealing with staff satisfaction surveys. Due to the ongoing economic crisis and poor financial standing of the hotel, this role should be temporarily given to the managers of individual departments. Their task should be to increase the level of motivation by exploring the expectations of employees, and then selecting the appropriate non-financial incentives.

\section{Conclusion}

The crisis should not be an excuse for companies to reject incentives. Managers work with insufficient knowledge in the belief that the only effective motivating factor is money. However, in times of crisis, when there is a lack of available resources for rewards, a number of tools can be used to offer non-financial incentives. Undoubtedly, this requires skill and strong commitment to communication with employees on the part of the managers. The most popular non-financial motivating factors respected by the staff are: optimally equipped work stations, working time matching the employee's needs, medical services package, extensive social plans, attractive excursions, cinema, theater, and sporting events tickets, subscription to useful journals.

Showing appreciation is also an important motivational tool. It is important that employees feel appreciated for their dedication to the tasks entrusted to them. Praise can take different forms and should be chosen accordingly, depending on the personality of the worker praised.

So, it is worthwhile to create mechanisms that will be an expression of appreciation, such as the provision of current feedback to managers, a system of collecting points for jobs well done, which translates into small prizes or various competitions, personal thankyou cards, lunch with representatives of senior management; the introduction of a reward for the "Employee of the Month" and "Employee of the Year".

Properly motivated people are the most valuable resource of hospitality businesses. The key to satisfaction and increase of intrinsic motivation is understanding the individual needs of employees and choosing the tools appropriate for each individual person.

Hotel staff is critical to the quality of services, and maintaining the highest level of guest service can help achieve satisfactory results even while the effects of the global economic crisis are still felt. It will also determine the competitive advantage after this difficult period has passed. Every recession in the economy has its end, and highly qualified and motivated staff will always be decisive for the economic results of hotel businesses.

\section{LIST OF REFERENCES}

1. Borkowska S.: Projektowanie strategii wynagrodzeń w przedsiębiorstwie. W: Zarządzanie strategiczne kapitałem ludzkim. Red. A. Ludwiczyński, K. Stobińska, Poltext, Warszawa 2001, s. 135. 
2. Juchnowicz M.: Systemy motywacyjne w warunkach zmian. W: Zarządzanie zmianami w zasobach pracy przedsiębiorstwa. Red. K. Makowski, SGH, Warszawa 1997, s. 134.

3. Lipka A.: Ryzyko personalne. Szanse i zagrożenia zarządzania zasobami ludzkimi. Poltext, Warszawa 2002, s. 82.

4. www.accorservices.pl

\title{
ЕКОНОМІЧНА КРИЗА ЯК ДЖЕРЕЛО МОТИВАЦІЙНОГО РИЗИКУ У ГОТЕЛЯРСТВІ НА ПРИКЛАДІ ГОТЕЛЮ NOVОТЕЦ У ЩЕЦИНІ
}

\author{
А. Токаж-Косік \\ Департамент менеджменту туризму \\ Щециинський університет \\ Щецин, Польщза
}

\begin{abstract}
Стаття складається 3 двох частин. У першій частині охарактеризовано основні зони мотиваційного ризику на підприємстві, у другій - представлено зміни у системі мотивації персоналу готелю Novotel у зв'язку з економічною кризою.

Стаття є результатом досліджень джерельних матеріалів та вивчення доступних вторинних даних, що торкаються аналізованого питання.

Ключові слова: економічна криза, мотиваційний ризик, готелярство, готель.
\end{abstract}

\section{ЭКОНОМИЧЕСКИЙ КРИЗИС КАК ИСТОЧНИК МОТИВАЦИОННОГО РИСКА В ОТЕЛЬНОМ БИЗНЕСЕ НА ПРИМЕРЕ ГОСТИНИЦЫ NOVOTEL В ЩЕЦИНЕ}

\author{
А. Токаж-Косик \\ Департамент менеджмента туризма \\ Щецинский университет \\ Щециин, Польша
}

Статья состоит из двух частей. В первой части охарактеризованы основные зоны мотивационного риска на предприятии, во второй - представлены изменения в системе мотивации персонала отеля Novotel в связи с экономическим кризисом.

Статья является результатом исследований исходных материалов и изучение доступных вторичных данных, касающихся рассматриваемого вопроса.

Ключевые слова: экономический кризис, мотивационный риск, готелярство, отель. 